\title{
The Effect of Organic vs. Conventional Cropping Systems on the Yield and Chemical Composition of Three Courgette Cultivars
}

\author{
Klaudia Kopczyńska ${ }^{1}$ D, Renata Kazimierczak ${ }^{1}$ (D), Dominika Średnicka-Tober ${ }^{1, *(D)}$, \\ Anna Szafirowska ${ }^{2}$, Marcin Barański ${ }^{1}$ (D), Ewa Rembiałkowska ${ }^{1}$ (D) and Ewelina Hallmann ${ }^{1}$ (D) \\ 1 Department of Functional and Organic Food, Institute of Human Nutrition Sciences, Warsaw University of \\ Life Sciences, Nowoursynowska 159c, 02-776 Warsaw, Poland; klaudia_kopczynska@sggw.edu.pl (K.K.); \\ renata_kazimierczak@sggw.edu.pl (R.K.); marcin_baranski@sggw.edu.pl (M.B.); \\ ewa_rembialkowska@sggw.edu.pl (E.R.); ewelina_hallmann@sggw.edu.pl (E.H.) \\ 2 Research Institute of Horticulture, Rybickiego 15/17, 96-100 Skierniewice, Poland; aszafir@onet.pl \\ * Correspondence: dominika_srednicka_tober@sggw.edu.pl; Tel.: +48-22-593-7035
}

Received: 7 August 2020; Accepted: 4 September 2020; Published: 6 September 2020

\begin{abstract}
Courgette is a popular vegetable belonging to the Cucurbitaceae family. It is known for its good adaptation to different weather conditions, although it performs best in a warm and humid climate. Since the yield and various quality characteristics of vegetables are known to be strongly influenced by a number of weather, agronomic, and genetic (variety/cultivar) factors, in this study we aimed to compare three cultivars of courgette (Atena, Lajkonik and Soraya) grown in two consecutive growing seasons in the organic and conventional agronomic systems. The concentrations of nitrates, nitrites, carotenoids (lutein, zeaxanthin, $\beta$-carotene) and chlorophylls (chlorophyll $a$, chlorophyll $b$ ) in courgette fruits were analyzed by HPLC. The growing season had a predominant effect on the yield as well as the majority of the analyzed compositional parameters of the courgette fruits. The studied cultivars differed significantly in the concentration of lutein, $\beta$-carotene, and chlorophylls, although some significant interactions between the cultivar and the growing season were observed. On average, organically grown courgettes were characterized by a significantly higher yield, as well as higher dry matter and chlorophyll content, however, this agronomic system's effect was not consistent among all the studied cultivars in the two seasons. The study suggests that organic practices have a potential to provide high yields of good quality crops, comparable (or, in the case of some parameters, better) than the conventional, resource-intensive horticulture.
\end{abstract}

Keywords: organic agriculture; conventional agriculture; courgette; Cucurbita pepo; yield; carotenoids; chlorophylls; nitrates; nitrites; HPLC

\section{Introduction}

Courgette, known also as zucchini, belongs to the large botanical family Cucurbitaceae [1], and is distinguished, next to, e.g., pumpkin, cocozelle, and marrow, as a representative of Cucurbita pepo species, subspecies pepo [2]. Courgettes and many other vegetables from the Cucurbitaceae family are popular and consumed on all continents [2], marketed both as fresh and processed products. The highest production of Cucurbitaceae has been noted in Spain, Poland, United States of America and Chile. However, the organic production of courgettes is marginal compared to the conventional production. According to Eurostat Statistics [3], in 2019 the conventional production of courgettes and marrows in the EU amounted to 1586.35 thousand tons, while in Poland it was 20.4 thousand tons. At the same time, organic production of courgettes, together with all organic vegetables cultivated for 
fruit (including melons), reached 446.20 thousand tons in the EU and 16.20 thousand tons in Poland. Data on organic courgettes only are not available.

Courgettes can be grown either from seeds or seedlings, in the open field or under cover [4]. Plants produce fruits in around 50 days after sowing and 40 days after transplanting [5]. Although they grow best in warm and humid weather, courgettes are generally known for their good adaptation to different environmental conditions, indicated by rather stable yielding [6,7].

Due to its adaptability and resistance to diseases and other agronomic and environmental stress factors, courgette seems to be perfectly suitable for cultivation in extensive agricultural systems, i.e., in the organic system. Organic horticulture relies on natural fertilizers such as manure and composts, natural plant protection strategies (biological, mechanical) and diverse crop rotations. As stated in the new European Council Regulation 2018/848 [8] on organic production, this type of farming aims to combine best environmental and climate action practices, support biodiversity and preservation of natural resources, and should apply the highest production standards, in line with the demand of a growing number of consumers for foods produced with the use of natural substances and processes. These aims of organic farming are closely in line with the Sustainable Development Goals of the United Nations [9]. Besides providing the environmental benefits, organic farming is expected to deliver crops and food products of high quality and safety. Indeed, the available research suggests that exposure to chemical pesticides can be significantly reduced and health-beneficial bioactive compound consumption can be increased by switching from the consumption of conventional to organically grown fruits and vegetables [10-16]. Taking into consideration the fact that the consumption of vegetables and fruits is, nowadays, strongly promoted, and that the organic food market, especially in Europe and the US is rapidly growing [17], characterization of the quality and overall performance of organically produced vegetables, including courgette, can undoubtedly count as a high interest of researchers, farmers and consumers. There are some studies on the yield and selected quality aspects of squashes cultivated in different cropping systems, e.g., soilless and hydroponic systems [18,19], or under drip irrigation [20], with different fertilization protocols [21,22]. However, the available research data on the performance and quality of Cucurbita pepo species grown in organic vs. conventional systems are very limited. Therefore, the aim of the present study was to characterize the yield as well as selected quality characteristics, including nitrates, nitrites, carotenoids and chlorophyll content, in the fruits of three courgette cultivars grown in two consecutive seasons according to organic and conventional farming standards.

\section{Materials and Methods}

\subsection{Study Design and Plant Material}

The research was conducted on three popular courgette cultivars (Atena, Lajkonik and Soraya) grown in two consecutive cultivation seasons in organic and conventional experimental plots of the Institute of Horticulture in Skierniewice, Poland ( $51^{\circ} 57^{\prime} \mathrm{N} 20^{\circ} 8^{\prime}$ E). Lajkonik and Soraya represent cultivars of courgette providing fruits with green skin, while Atena fruits are characterized by yellow skin. The most important information about the field experiment, including the agronomic practices applied, is presented in Table 1. The organic experimental field was established in 2002 in an area of 5 ha, with rimmed buffer strips ensuring high biodiversity. Both the organic and the conventional field are located on podzolic soil with $1.05-1.15 \%$ of organic matter and soil $\mathrm{pH}$ of $6.7-7.0$. The two-factorial experimental design included 24 plots (size of a single plot: $10 \mathrm{~m}^{2}$ ), with four replicate plots for each combination of two cultivation systems and three cultivars. In both cultivation systems, the plots were mulched with black non-woven polypropylene agrotextile $\left(50 \mathrm{~g} / \mathrm{m}^{2}, \mathrm{BPP} 50\right)$. Neither disease nor pest control was applied in the experiment. Three years of crop rotation (vegetables-cereals-legumes mixed with cereals) was used in both cultivation systems. Conventional plots were fertilized with multicomponent mineral fertilizer, providing $120 \mathrm{~kg} / \mathrm{ha}$ of nitrogen, $275 \mathrm{~kg} / \mathrm{ha}$ of phosphorus and $256 \mathrm{~kg} / \mathrm{ha}$ of potassium every year. The nitrogen fertilization was applied before and after planting 
(in total $120 \mathrm{~kg} / \mathrm{ha}$, urea). Organic plots were supplied with nutrients from red clover and rye straw as well as the organic compost ( $20 \mathrm{t} / \mathrm{ha}$ ) incorporated into the soil before planting. Courgette sowing in both systems started in the beginning of May. Seeds were sown into multiplates for transplant production. Transplanting took place in mid-June. The fruits were harvested six times, between 24 July and 4 October.

Table 1. Agronomic conditions and practices applied in the organic vs. conventional courgette cultivation.

\begin{tabular}{|c|c|c|}
\hline $\begin{array}{l}\text { Agronomic Conditions and } \\
\text { Practices }\end{array}$ & Organic Field & Conventional Field \\
\hline Type of soil & \multicolumn{2}{|c|}{ podzolic soil $1.05-1.15 \%$ organic matter } \\
\hline $\mathrm{pH}$ & 6.8 & 7.0 \\
\hline Plot size & $10 \mathrm{~m}^{2}$ & $10 \mathrm{~m}^{2}$ \\
\hline No. of field replications & 4 & 4 \\
\hline Weed control & \multicolumn{2}{|c|}{ polypropylene agrotextile mulching (50 g/m² BPP50) } \\
\hline Crop rotation & \multicolumn{2}{|c|}{ vegetables, cereals, legumes mixed with cereals } \\
\hline Fertilization & $\begin{array}{l}\text { red clover + rye straw } \\
\text { compost } 20 \text { t/ha }\end{array}$ & mineral \\
\hline Nitrogen $(\mathrm{N})$ & $140 \mathrm{~kg} / \mathrm{ha}$ & $120 \mathrm{~kg} / \mathrm{ha}$ (urea) \\
\hline Phosphorus (P) & $80 \mathrm{~kg} / \mathrm{ha}$ & 275 kg/ha (superphosphate) \\
\hline \multirow[t]{3}{*}{ Potassium $(\mathrm{K})$} & $160 \mathrm{~kg} / \mathrm{ha}$ & $\begin{array}{c}256 \mathrm{~kg} / \mathrm{ha} \text { (hydrated potassium } \\
\text { sulfate) }\end{array}$ \\
\hline & \multicolumn{2}{|c|}{ Calendar of Sowing and Harvesting } \\
\hline & 2012 & 2013 \\
\hline Sowing date & 6 May & 4 May \\
\hline Transplanting date & 14 June & 20 June \\
\hline Harvest time & \multicolumn{2}{|c|}{24 July-4 October } \\
\hline
\end{tabular}

Information about weather conditions (sunshine hours, rainfall, humidity and temperatures) in both experimental years are presented in Figure 1.

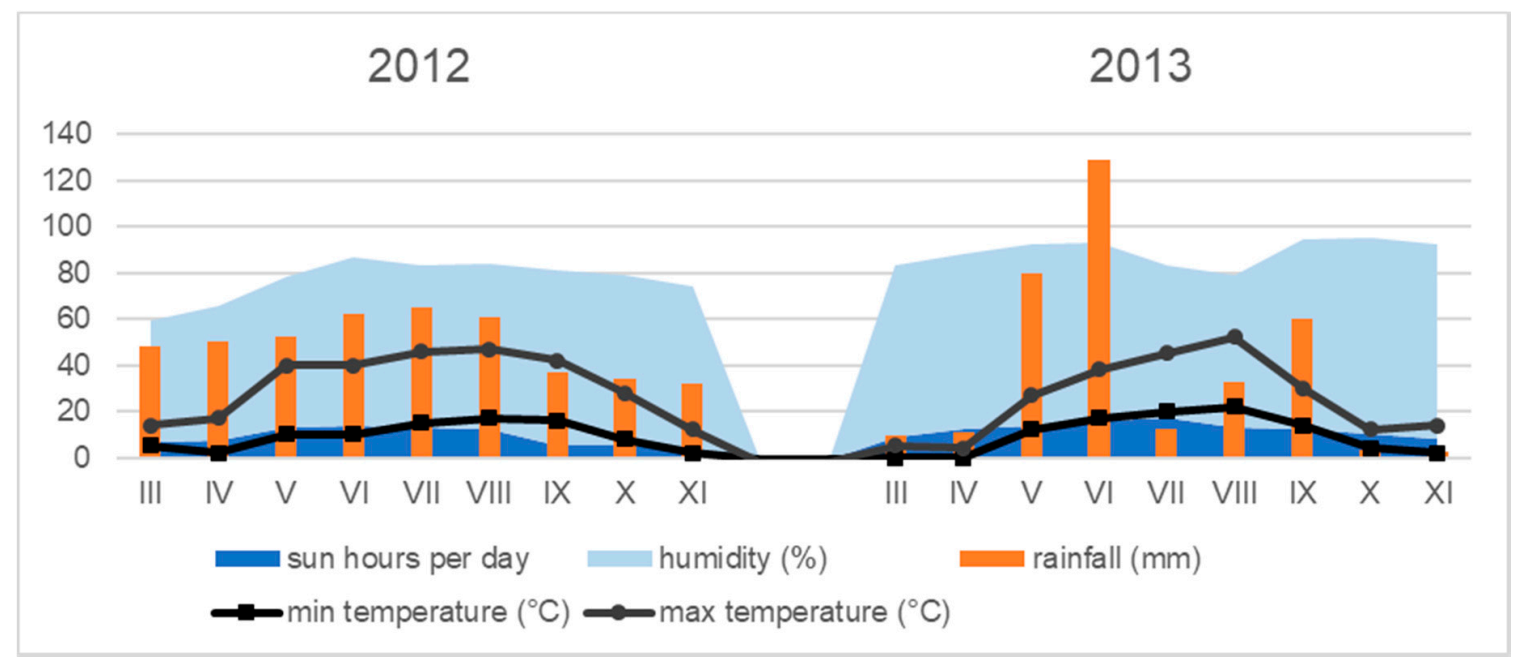

Figure 1. Weather conditions at the experimental station in Skierniewice, Poland, in 2012 and 2013 vegetation seasons. 


\subsection{Yield Analysis}

Each year courgette fruits from all experimental plots (four replicate plots of each of the two growing systems $\times$ three cultivar combinations) were harvested six times, between 24 July and 4 October. Within each plot and combination, fruits were additionally grouped depending on their length (small: 7-14 cm, medium: 15-21 cm, long: 22-30 cm). Within each size (length), all fruits were counted and weighted, to determine the yield. The yield was expressed in tons per hectare and thousands of fruits per hectare. Additionally, the average fruit weight (in g) was calculated.

\subsection{Preparation of Fruit Samples for Analyses}

The random fresh fruits samples from each experimental plot, from two harvests in each season (6 August and 5 September 2012; 27 August and 4 October 2013), were transported to the Department of Functional and Organic Food, Warsaw University of Life Sciences (Warsaw, Poland) for the dry matter and chemical composition analyses. Fruits were washed and cut into cubes $(5 \times 5 \times 5 \mathrm{~mm})$. Fresh fruit samples were used for dry matter content analysis. At the same time, $100 \mathrm{~g}$ samples were frozen $\left(-80^{\circ} \mathrm{C}\right.$ for $\left.24 \mathrm{~h}\right)$ and subjected to a freeze-drying process using a Labcono 2.5 freeze-dryer (Labconco Corporation, Kansas City, MO, USA). The freeze-drying process was carried out at $-40{ }^{\circ} \mathrm{C}$ and the pressure of $0.100 \mathrm{mBa}$. After freeze-drying, the samples were ground in a laboratory mill A-11 (IKA ${ }^{\circledR}$-Werke GmbH \& Co. KG, Staufen im Breisgau, Germany) and stored in scintillation vials at $-80^{\circ} \mathrm{C}$ until further analyses of carotenoids, chlorophylls, nitrates and nitrites content.

\subsection{Dry Matter}

Dry matter analysis was carried out according to the procedure described in Polish Norm PN-EN-12145:2001 [23]. Fresh courgette fruit samples (15-20 g) were subjected to a drying process in $105^{\circ} \mathrm{C}$, with free air circulation (FP-25W Farma Play dryer, Farma Play, Marki, Poland) for $72 \mathrm{~h}$. The dried samples were cooled in desiccator and weighted. The content of dry matter was calculated in $g$ per $100 \mathrm{~g}$ fresh matter [24].

\subsection{Chemicals}

Acetone (HPLC grade) from Sigma-Aldrich (Poznań, Poland); carotenoids and chlorophylls standards: $\beta$-carotene, chlorophyll a, chlorophyll b, lutein (HPLC grade $99.5-99.9 \%$ pure) from Fluka and Sigma-Aldrich (Poznań, Poland); Carrez I (15\% potassium ferrocyanide) from Chempur (Piekary Ślaskie, Poland); Carrez II (30\% potassium sulfate liquid) from Chempur (Piekary Ślaskie, Poland).

\subsection{Nitrates and Nitrites Extraction and Identification}

The concentrations of nitrates and nitrites in courgette fruits were determined with high-performance liquid chromatography (HPLC) method, according to PN-EN Norm (12014-2) [25]. For each sample, the freeze-dried plant material $(50 \mathrm{mg})$ was weighted into a plastic tube. The samples were deproteinized by two Carrez solutions and filtered. The extract was used for the HPLC analysis, with Shimadzu equipment (two LC-20AD pumps, CMB-20A system controller, SIL-20AC autosampler, UV-Vis SPD-20AV detector, Shimadzu, USA Manufacturing Inc., Canby, OR, USA). Hamilton column $(150 \times 4.1$ PRP-x100) was used. The injection volume was $100 \mu \mathrm{L}$. The isocratic gradient was applied. The mobile phase was $2.0 \mathrm{mM}$ sodium benzoate $\left(\mathrm{pH}\right.$ 6.5). Oven temperature was set at $21^{\circ} \mathrm{C}$, flow rate was $1 \mathrm{~mL} / \mathrm{min}$. The wavelength used for detection was $260 \mathrm{~nm}$. The contents of nitrates and nitrites were calculated on the standard solution base [26].

\subsection{Carotenoid and Chlorophyll Extraction and Identification}

The carotenoids and chlorophylls were analyzed using HPLC protocol previously described in Średnicka-Tober et al. (2019) [27]. Freeze-dried courgette fruit powder (100 mg) was mixed with $5 \mathrm{~mL}$ of pure acetone by Vortex mixer. Samples were incubated in ultrasonic bath $\left(15 \mathrm{~min}, 0^{\circ} \mathrm{C}\right)$ and 
centrifuged ( $6000 \mathrm{rpm}, 10 \mathrm{~min}, 0^{\circ} \mathrm{C}$ ). Supernatant was transferred to dark HPLC vials. The compounds were determined using the previously described Shimadzu HPLC. A Max-RP 80A column $(250 \times$ $4.6 \mathrm{~mm}$ ) was used. The injection volume was $100 \mu \mathrm{L}$. The wavelength of $445-450 \mathrm{~nm}$ was used for detection. Time of analysis was $18 \mathrm{~min}$. The example of a chromatogram showing peaks for individual compounds is presented in Figure 2. The compounds were identified by comparing their retention times to those of the authentic standards (Fluka and Sigma-Aldrich, Poznań, Poland, purity of 99.98\%).

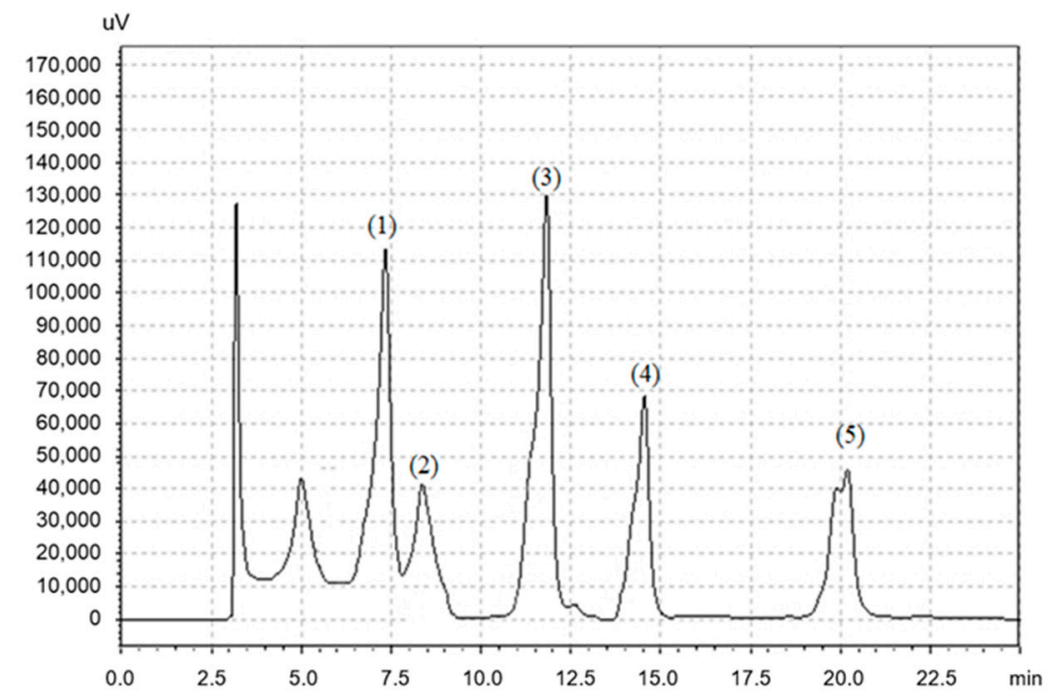

Figure 2. The chromatogram showing retention times and peak areas for lutein (1), zeaxanthin (2), chlorophyll $b$, (3) chlorophyll $a$, (4) $\beta$-carotene (5).

\subsection{Statistical Analysis}

The statistical analyses were carried out in the R statistical environment [28]. First, the normality of data distribution was tested using the qqnorm function in R. Not normally distributed data were transformed as necessary. The cube root transformation was applied to data on the concentration of dry matter, nitrates, nitrites, sum of carotenoids and chlorophyll a. The logarithm transformation was applied to data on the concentration of lutein, zeaxanthin and sum of chlorophylls. Data on the concentration of chlorophyll $b$ and $\beta$-carotene did not need to be transformed. The 3 -factor Analyses of Variance (ANOVA) were performed using a linear-mixed effects model, with growing year, courgette cultivar, and cultivation system as fixed effect factors, and harvest date and fruit size as random effect factors. This allowed to test the significance of the experimental factors and their interactions. Next, the 2-factor ANOVA was carried out, to explain the identified interactions. The significance of the differences between interaction means was tested by Tukey's HSD post hoc test.

\section{Results and Discussion}

\subsection{Yield Parameters}

The average marketable yield of courgette fruits in the experiment amounted to $22.6 \pm 1.05 \mathrm{~kg}$ per experimental plot, which means $22.6 \pm 1.05$ tons/ha, composed of $88.85 \pm 4.07$ thousands of fruits/ha, with the average weight of a single fruit reaching $0.26 \pm 0.01 \mathrm{~kg}$. The greatest part of the yield (in $\mathrm{kg}$ ) was represented by the large $(22-30 \mathrm{~cm})$ fruits $(13.33 \pm 0.73 \mathrm{tons} / \mathrm{ha})$, while the number of fruits was greatest in the case of small $(7-14 \mathrm{~cm})$ fruits $(37.60 \pm 2.31$ thousands of fruits/ha). The fruit yield was affected by all the three experimental factors: year of cultivation, cultivar and the growing system. On average, the yield was higher in 2013 compared to the 2012 cultivation season (total yield in $\mathrm{kg}$, number of harvested fruit, as well as the average fruit weight), higher in Atena compared to the other two cultivars, and significantly higher in the organic compared to the conventional cropping system (Table 2). However, significant interactions between the experimental factors were also observed, 
e.g., the described effects of the production system and cultivation year were observed in the case of Atena and Soraya but not in the Lajkonik cultivar (Figures 3 and 4). The average fruit weight was generally higher in the case of fruits harvested in 2013 vs. 2012, in those coming from the organic vs. conventional system, and in the case of Soraya compared to the two other cultivars (Table 2). However, these outcomes were not consistent for all experimental combinations, e.g., a statistically significant impact of the cultivation year was observed only in the case of Soraya cultivar (Figure 5).
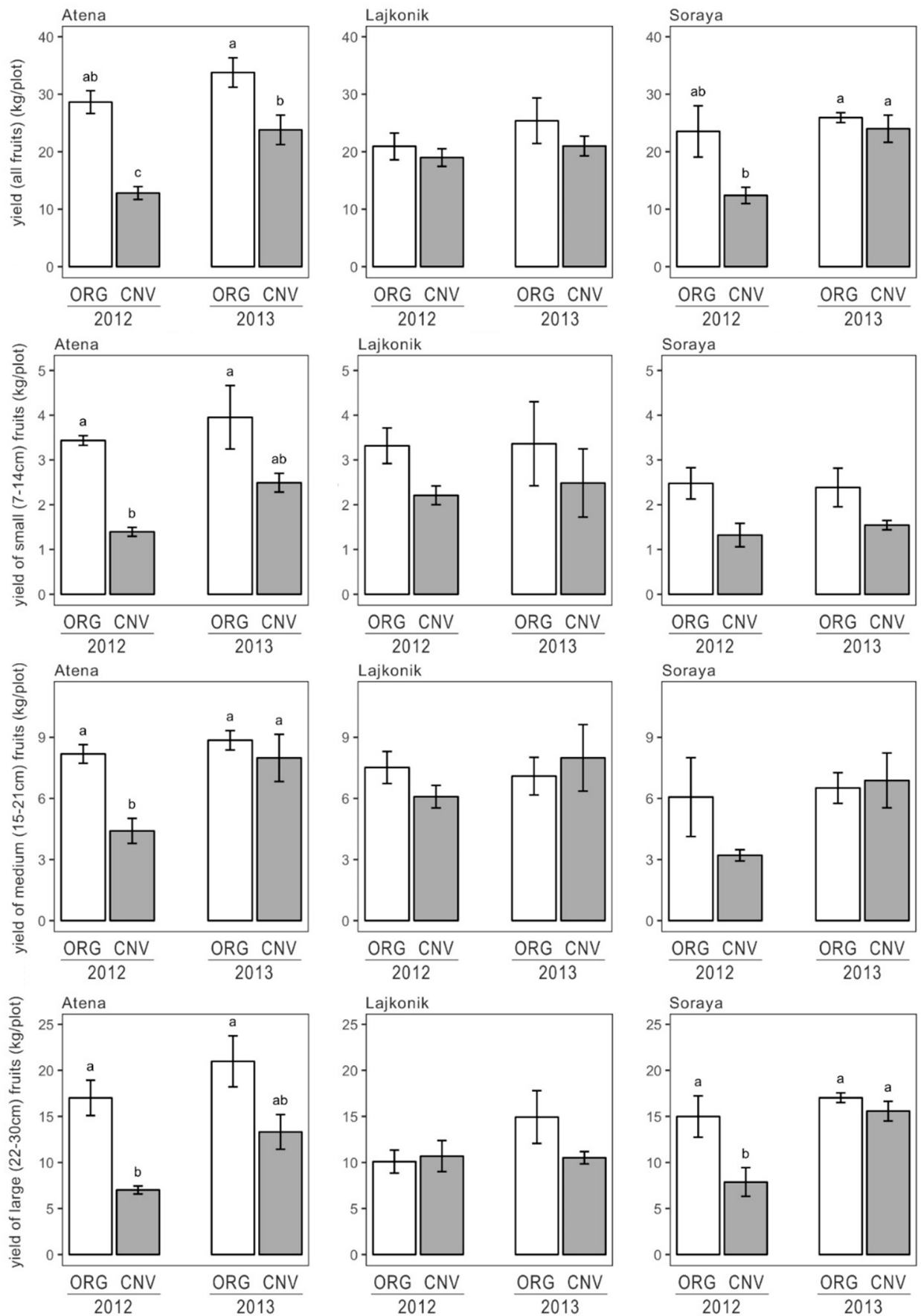

Figure 3. Total yield $(\mathrm{kg} / \mathrm{plot}=$ tons $/$ ha $)$ of all $(7-30 \mathrm{~cm})$, small $(7-14 \mathrm{~cm})$, medium $(15-21 \mathrm{~cm})$ and large $(22-30 \mathrm{~cm})$ organic (ORG) and conventional $(\mathrm{CNV})$ courgette fruits of Atena, Lajkonik and Soraya cultivars grown in two consecutive years. Data are presented as means with standard errors. Within each cultivar, bars marked with the same letters are not significantly different at the $5 \%$ level of probability. 
Table 2. The main effects of, and interactions between, cultivation year, cultivar and agronomic system on the yield of small (7-14 $\mathrm{cm})$, medium (15-21 $\mathrm{cm})$ and large $(22-30 \mathrm{~cm})$ courgette fruits and the average fruit weight.

\begin{tabular}{|c|c|c|c|c|c|c|c|c|c|}
\hline \multirow[t]{2}{*}{ Factor } & \multicolumn{4}{|c|}{ Yield (tons/ha) } & \multicolumn{4}{|c|}{ Yield (Fruits $\times 10^{3} /$ ha) } & \multirow{2}{*}{$\begin{array}{c}\text { Average Fruit } \\
\text { Weight (kg) }\end{array}$} \\
\hline & $7-14 \mathrm{~cm}$ & $15-21 \mathrm{~cm}$ & $22-30 \mathrm{~cm}$ & All & $7-14 \mathrm{~cm}$ & $15-21 \mathrm{~cm}$ & $22-30 \mathrm{~cm}$ & All & \\
\hline \multicolumn{10}{|c|}{ Cultivation Year (CY) } \\
\hline 2012 & $2.36 \pm 0.20^{1}$ & $5.91 \pm 0.49$ & $11.3 \pm 1.0$ & $19.5 \pm 1.5$ & $37.6 \pm 2.7$ & $25.9 \pm 1.9$ & $20.1 \pm 1.6$ & $83.6 \pm 5.6$ & $0.235 \pm 0.009$ \\
\hline 2013 & $2.70 \pm 0.27$ & $7.56 \pm 0.44$ & $15.4 \pm 1.0$ & $25.6 \pm 1.2$ & $37.6 \pm 3.8$ & $32.9 \pm 2.1$ & $23.6 \pm 1.2$ & $94.1 \pm 5.9$ & $0.288 \pm 0.016$ \\
\hline \multicolumn{10}{|l|}{ Cultivar (CV) } \\
\hline Atena & $2.82 \pm 0.30 \mathrm{a}^{2}$ & $7.36 \pm 0.56$ & $14.6 \pm 1.6$ & $24.8 \pm 2.2$ & $50.2 \pm 3.8 \mathrm{a}$ & $35.1 \pm 2.2 \mathrm{a}$ & $25.6 \pm 2.2 \mathrm{a}$ & $110.9 \pm 7.4 \mathrm{a}$ & $0.219 \pm 0.010 b$ \\
\hline Lajkonik & $2.84 \pm 0.32 \mathrm{a}$ & $7.17 \pm 0.50$ & $11.6 \pm 1.0$ & $21.6 \pm 1.3$ & $38.5 \pm 2.9 \mathrm{~b}$ & $32.0 \pm 2.2 \mathrm{a}$ & $18.9 \pm 1.0 \mathrm{~b}$ & $89.4 \pm 3.6 b$ & $0.243 \pm 0.012 b$ \\
\hline Soraya & $1.93 \pm 0.19 b$ & $5.67 \pm 0.67$ & $13.9 \pm 1.1$ & $21.5 \pm 1.8$ & $24.1 \pm 2.2 c$ & $21.1 \pm 2.0 \mathrm{~b}$ & $21.1 \pm 1.5 \mathrm{ab}$ & $66.3 \pm 4.6 c$ & $0.322 \pm 0.016 \mathrm{a}$ \\
\hline \multicolumn{10}{|c|}{ Agronomic System (AS) } \\
\hline organic & $3.16 \pm 0.23$ & $7.37 \pm 0.42$ & $15.8 \pm 1.0$ & $26.4 \pm 1.4$ & $42.8 \pm 3.4$ & $31.9 \pm 2.1$ & $25.2 \pm 1.4$ & $99.9 \pm 5.8$ & $0.274 \pm 0.014$ \\
\hline conventional & $1.91 \pm 0.17$ & $6.09 \pm 0.53$ & $10.8 \pm 0.8$ & $18.8 \pm 1.2$ & $32.4 \pm 2.8$ & $26.9 \pm 2.1$ & $18.5 \pm 1.2$ & $77.8 \pm 4.9$ & $0.249 \pm 0.013$ \\
\hline \multicolumn{10}{|l|}{ ANOVA $p$-values } \\
\hline CY & $\mathrm{NS}^{3}$ & 0.009 & $<0.001$ & $<0.001$ & NS & 0.001 & 0.013 & 0.015 & $<0.001$ \\
\hline $\mathrm{CV}$ & 0.013 & 0.051 & 0.051 & NS & $<0.001$ & $<0.001$ & 0.001 & $<0.001$ & $<0.001$ \\
\hline AS & $<0.001$ & 0.039 & $<0.001$ & $<0.001$ & 0.001 & 0.017 & $<0.001$ & $<0.001$ & 0.023 \\
\hline $\mathrm{CY} \times \mathrm{CV}$ & NS & NS & NS & NS & 0.010 & NS & NS & 0.007 & 0.009 \\
\hline $\mathrm{CY} \times \mathrm{AS}$ & NS & 0.023 & NS & NS & 0.042 & 0.005 & 0.007 & $<0.001$ & NS \\
\hline $\mathrm{CV} \times \mathrm{AS}$ & NS & NS & 0.027 & 0.026 & NS & NS & 0.029 & 0.013 & NS \\
\hline $\mathrm{CY} \times \mathrm{CV} \times \mathrm{AS}$ & NS & NS & NS & NS & NS & NS & NS & NS & NS \\
\hline
\end{tabular}

${ }^{2}$ Data are presented as means \pm standard errors; ${ }^{2}$ Values in columns followed by different letters are significantly different at the $5 \%$ level of probability; ${ }^{3}$ NS- not significant $(p>0.05)$. 

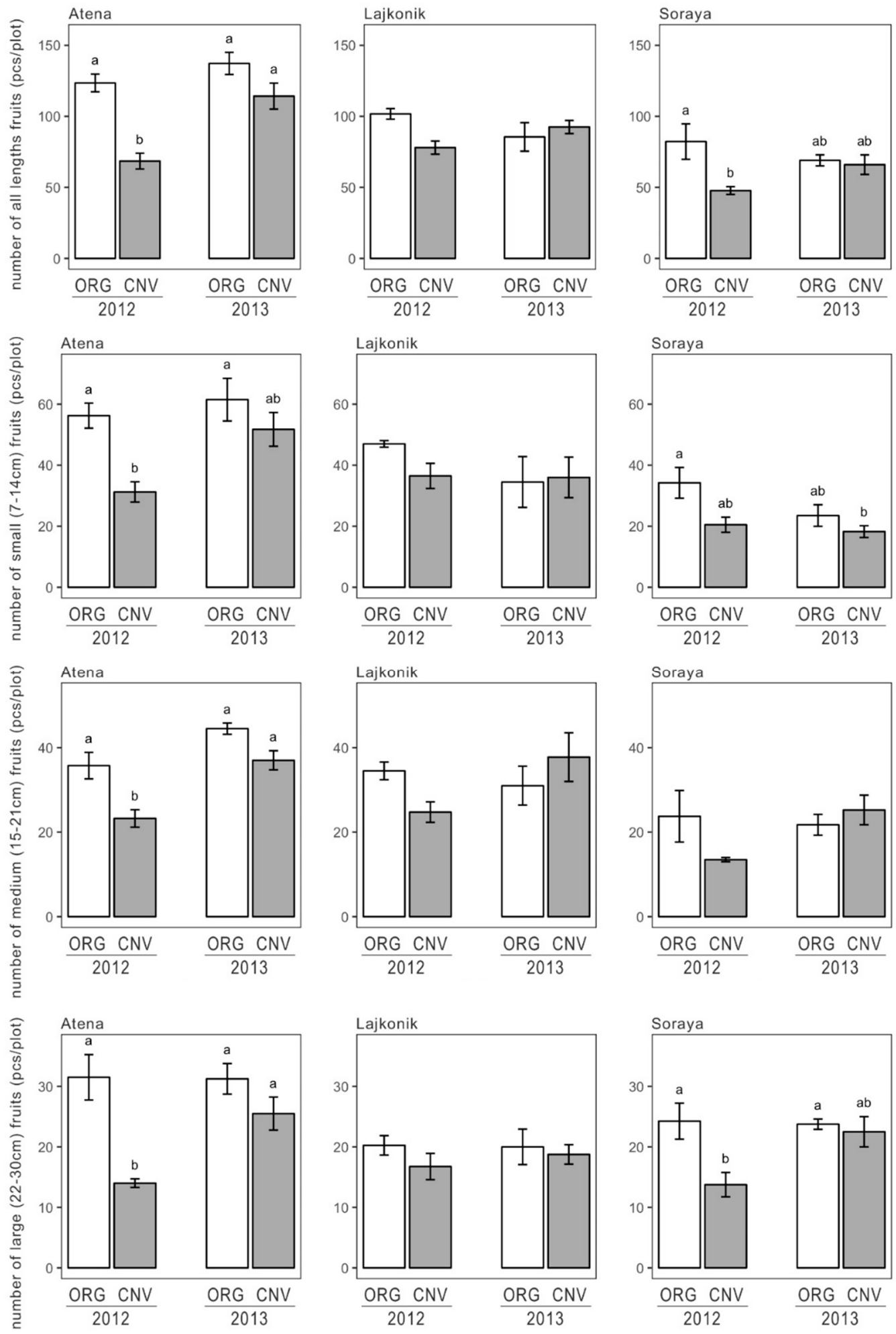

Figure 4. Number $\left(\mathrm{pcs} / \mathrm{plot}=\mathrm{pcs} \times 10^{3} / \mathrm{ha}\right)$ of all $(7-30 \mathrm{~cm})$, small $(7-14 \mathrm{~cm})$, medium $(15-21 \mathrm{~cm})$ and large $(22-30 \mathrm{~cm})$ organic (ORG) and conventional $(\mathrm{CNV})$ courgette fruits of Atena, Lajkonik and Soraya cultivars grown in two consecutive years. Data are presented as means with standard errors. Within each cultivar, bars marked with the same letters are not significantly different at the $5 \%$ level of probability. 

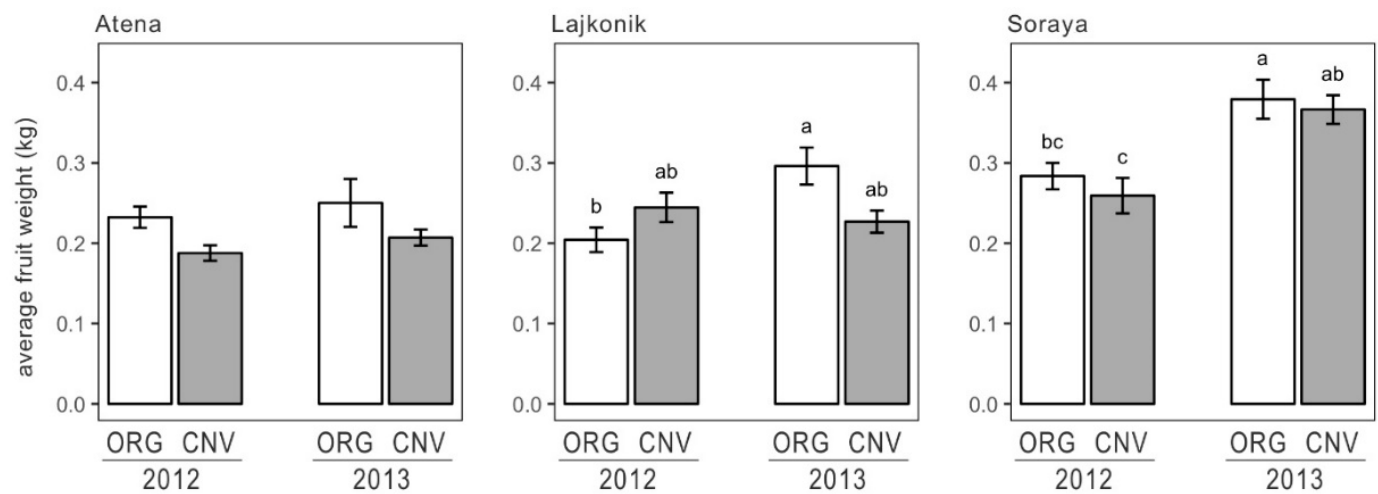

Figure 5. Average fruit weight of organic (ORG) and conventional (CNV) courgette of Atena, Lajkonik and Soraya cultivars grown in two consecutive years. Data are presented as means with standard errors. Within each cultivar, bars marked with the same letters are not significantly different at the $5 \%$ level of probability.

Inconsistent yielding results in unstable incomes and makes sales planning more difficult. Thus, yield and its stability over the years are among the most important parameters for farmers, often determining cultivar selection for growing. Looking through this perspective, results of the presented study indicate that in the conventional system, Lajkonik cultivar of courgette was characterized by the most stable yields across growing seasons. Yields of courgette fruits grown in the organic system were much more stable over the years, which was confirmed in the case of all three cultivars tested (Figure 3).

\subsection{Dry Matter Content}

Courgette fruits are characterized by high water and low dry matter content. The average dry matter content in the courgette fruits analyzed within the study reached $5.45 \pm 0.08 \mathrm{~g} / 100 \mathrm{~g}$ f.w. Among the three factors, cultivation year appeared to be a predominant factor differentiating the dry matter content in the fruits. Courgettes grown in 2012 were characterized by a higher dry matter content than those cultivated in 2013 (Table 3). Moreover, on average, organic courgettes contained more dry matter than conventional courgettes (Table 3), although this was significant only in the case of Soraya (Figure 6). A study comparing the dry matter content in the mesocarp and epicarp of Cucurbita pepo fruits showed greater contents in epicarp than mesocarp, with contents in epicarp similar to those obtained in the present study [29]. The dry matter content is considered an important feature for sensory assessment of fruits. Dry matter content in buttercup squash fruits between $20 \%$ and $28 \%$ was noted as acceptable for direct consumption, while fruits with a dry matter content over $28 \%$ were qualified for processing purposes [30]. This feature was considered crucial in breeding programs of Cucurbita maxima to obtain the best crops, matching consumer preferences [1,31]. Another experiment also showed a strong dependence of sensory assessment on the dry matter content of Cucurbita maxima and moschata fruits [32]. Usually, consumers prefer fruits with higher dry matter content [1,29]. In view of these aspects, it can be considered that the dry matter content in courgette fruits is an important factor for sensory desirability and should be examined in future research. 
Table 3. The main effects of, and interactions between, cultivation year, cultivar and agronomic system on the content of dry matter, nitrites, nitrates, carotenoids and chlorophylls in the courgette fruits.

\begin{tabular}{|c|c|c|c|c|c|c|c|c|c|c|}
\hline Factor & $\begin{array}{l}\text { Dry Matter } \\
\text { (g/100 g f.w.) }\end{array}$ & $\begin{array}{c}\text { Nitrites } \\
\text { (mg/kg f.w.) }\end{array}$ & $\begin{array}{c}\text { Nitrates } \\
\text { (mg/kg f.w.) }\end{array}$ & $\begin{array}{l}\text { Carotenoids } \\
\text { ( } \mu \mathrm{g} / \mathrm{g} \text { f.w.) }\end{array}$ & $\begin{array}{l}\text { Lutein }(\mu \mathrm{g} / \mathrm{g} \\
\text { f.w.) }\end{array}$ & $\begin{array}{c}\text { Zeaxanthin } \\
\text { ( } \mu \mathrm{g} / \mathrm{g} \text { f.w.) }\end{array}$ & $\begin{array}{l}\beta \text {-carotene } \\
\text { ( } \mu \mathrm{g} / \mathrm{g} \text { f.w.) }\end{array}$ & $\begin{array}{l}\text { Chlorophylls } \\
\text { (mg/100 g } \\
\text { f.w.) }\end{array}$ & $\begin{array}{l}\text { Chlorophyll } \\
a \text { (mg/100 g } \\
\text { f.w.) }\end{array}$ & $\begin{array}{l}\text { Chlorophyll } \\
b \text { (mg/100 g } \\
\text { f.w.) }\end{array}$ \\
\hline \multicolumn{11}{|c|}{ Cultivation Year (CY) } \\
\hline 2012 & $5.66 \pm 0.08^{1}$ & $1.52 \pm 0.05$ & $29.33 \pm 0.95$ & $12.38 \pm 0.20$ & $5.65 \pm 0.14$ & $4.11 \pm 0.06$ & $2.62 \pm 0.04$ & $4.28 \pm 0.11$ & $2.94 \pm 0.09$ & $1.34 \pm 0.05$ \\
\hline 2013 & $5.24 \pm 0.14$ & $0.88 \pm 0.02$ & $13.28 \pm 0.33$ & $12.23 \pm 0.22$ & $4.38 \pm 0.07$ & $6.06 \pm 0.11$ & $1.80 \pm 0.06$ & $4.87 \pm 0.18$ & $3.02 \pm 0.14$ & $1.86 \pm 0.04$ \\
\hline \multicolumn{11}{|l|}{ Cultivar (CV) } \\
\hline Atena & $5.62 \pm 0.14 \mathrm{a}^{2}$ & $1.23 \pm 0.06 \mathrm{a}$ & $21.93 \pm 1.27 \mathrm{a}$ & $12.04 \pm 0.28 \mathrm{~b}$ & $5.01 \pm 0.18 \mathrm{ab}$ & $5.02 \pm 0.15 \mathrm{a}$ & $2.01 \pm 0.09 \mathrm{~b}$ & $3.89 \pm 0.10 \mathrm{~b}$ & $2.37 \pm 0.09 b$ & $1.52 \pm 0.05 \mathrm{a}$ \\
\hline Lajkonik & $5.52 \pm 0.15 \mathrm{a}$ & $1.22 \pm 0.06 \mathrm{a}$ & $21.39 \pm 1.32 \mathrm{a}$ & $12.20 \pm 0.23 a b$ & $4.71 \pm 0.11 \mathrm{~b}$ & $5.11 \pm 0.15 \mathrm{a}$ & $2.38 \pm 0.07 a$ & $5.51 \pm 0.15 \mathrm{a}$ & $3.85 \pm 0.11 \mathrm{a}$ & $1.66 \pm 0.06 \mathrm{a}$ \\
\hline Soraya & $5.21 \pm 0.11 \mathrm{a}$ & $1.15 \pm 0.06 \mathrm{a}$ & $20.59 \pm 1.28 \mathrm{a}$ & $12.68 \pm 0.27 \mathrm{a}$ & $5.33 \pm 0.16 \mathrm{a}$ & $5.11 \pm 0.17 \mathrm{a}$ & $2.24 \pm 0.07 \mathrm{a}$ & $4.33 \pm 0.23 b$ & $2.72 \pm 0.17 b$ & $1.61 \pm 0.07 \mathrm{a}$ \\
\hline \multicolumn{11}{|c|}{ Agronomic System (AS) } \\
\hline organic & $5.57 \pm 0.10$ & $1.23 \pm 0.05$ & $20.48 \pm 0.95$ & $12.36 \pm 0.20$ & $4.97 \pm 0.10$ & $5.15 \pm 0.13$ & $2.24 \pm 0.06$ & $4.71 \pm 0.16$ & $3.09 \pm 0.13$ & $1.62 \pm 0.05$ \\
\hline conventional & $5.33 \pm 0.13$ & $1.17 \pm 0.05$ & $22.12 \pm 1.14$ & $12.26 \pm 0.23$ & $5.06 \pm 0.15$ & $5.01 \pm 0.13$ & $2.18 \pm 0.06$ & $4.44 \pm 0.14$ & $2.87 \pm 0.11$ & $1.58 \pm 0.05$ \\
\hline \multicolumn{11}{|c|}{ ANOVA $p$-values } \\
\hline CY & $<0.001$ & $<0.001$ & $<0.001$ & NS & $<0.001$ & $<0.001$ & $<0.001$ & 0.002 & NS & $<0.001$ \\
\hline $\mathrm{CV}$ & $\mathrm{NS}^{3}$ & NS & NS & 0.047 & $<0.001$ & NS & $<0.001$ & $<0.001$ & $<0.001$ & 0.017 \\
\hline AS & 0.035 & NS & NS & NS & NS & NS & NS & 0.043 & 0.036 & NS \\
\hline $\mathrm{CY} \times \mathrm{CV}$ & NS & NS & NS & 0.022 & 0.009 & NS & $<0.001$ & $<0.001$ & $<0.001$ & 0.007 \\
\hline $\mathrm{CY} \times \mathrm{AS}$ & NS & NS & 0.029 & NS & 0.050 & NS & 0.046 & NS & NS & NS \\
\hline $\mathrm{CV} \times \mathrm{AS}$ & NS & NS & NS & NS & 0.002 & NS & 0.042 & NS & NS & NS \\
\hline $\mathrm{CY} \times \mathrm{CV} \times \mathrm{AS}$ & NS & NS & NS & NS & NS & NS & NS & NS & NS & NS \\
\hline
\end{tabular}

\footnotetext{
${ }^{1}$ Data are presented as means \pm standard errors; ${ }^{2}$ Values in columns followed by different letters are significantly different at the $5 \%$ level of probability; ${ }^{3}$ Not significant $(p>0.05)$.
} 

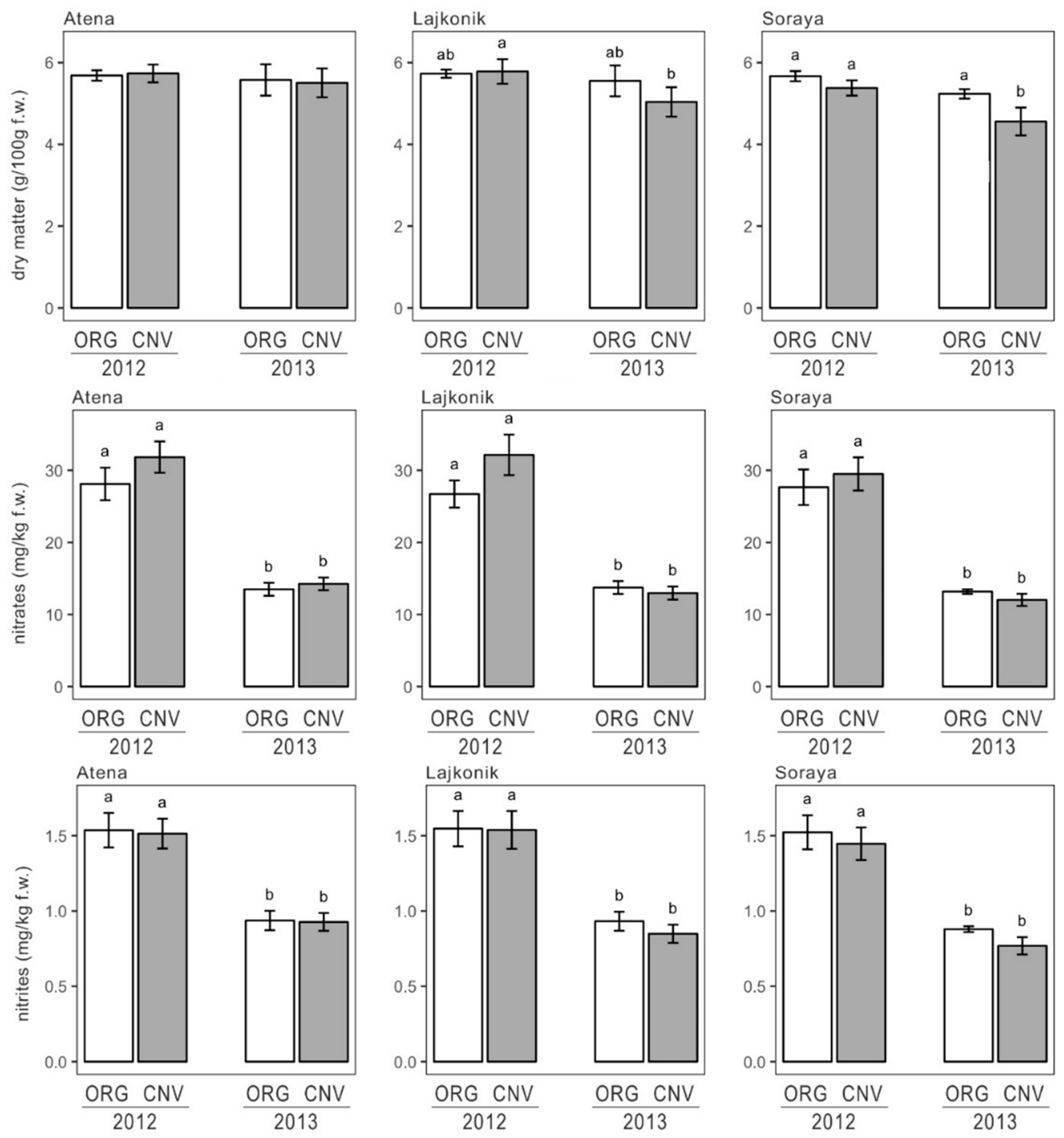

Figure 6. Dry matter, nitrates and nitrites content in organic (ORG) and conventional (CNV) courgette fruits of Atena, Lajkonik and Soraya cultivars grown in two consecutive years. Data are presented as means with standard errors. Within each cultivar, bars marked with the same letters are not significantly different at the $5 \%$ level of probability.

\subsection{Nitrates and Nitrites Content}

The content of nitrates and nitrites in the courgette fruits analyzed within the study reached, on average, $21.30 \pm 0.74 \mathrm{mg} / \mathrm{kg}$ f.w. and $1.20 \pm 0.03 \mathrm{mg} / \mathrm{kg}$ f.w., respectively, and varied significantly between the fruits grown in the 2012 and 2013 seasons. Fruits cultivated in 2012 were more abundant in nitrites and nitrates than those grown in 2013, regardless of the cultivar and agronomic system (Table 3). At the same time, no significant differences in the content of nitrates and nitrites between organic and conventional fruits and between the tested cultivars were observed (Table 3 and Figure 6).

According to the available research, nitrate concentration in plants depends on many factors, such as open field vs. greenhouse farming [33], irrigation with calcium [34], fruit development stage [35,36], organic vs. conventional production system $[36,37]$ and especially type and doses of nitrogen fertilizers used in cultivation [38]. Some researchers point out that nitrate content depends also on climate and weather conditions, plant variety, and on the soil type [39].

Dietary nitrites intake is widely considered to be potentially harmful for human health, as these compounds have been described as a risk factor for stomach cancer and methemoglobinemia in 
humans [40]. Although there is a considerable controversy on whether nitrates naturally occurring in vegetables also should be considered as a food safety hazard, high concentrations of nitrates and nitrites, especially in foods intended for infants and children, are considered not desirable [40-42].

Nitrogen in organic fertilizers is not as soluble and freely available as in the synthetic fertilizers, and thus plants grown in the organic cropping systems, fertilized with manures and compost, usually absorb nitrogen slower than the plants grown in the intensive, conventional systems where high doses of synthetic, mineral nitrogen fertilizers are applied [38,43]. However, fruits of Cucurbitaceae family are generally characterized by a low tendency to nitrate and nitrite accumulation [44,45]. Nitrate content in marrow, squash, pumpkin, gourd and courgette was previously reported to reach $200-500 \mathrm{mg} / \mathrm{kg}$ f.w. $[38,39,46,47]$, which represented greater values than those found in the present study. Other authors have found $73 \mathrm{mg}$ of nitrates in $1 \mathrm{~kg}$ of fresh small courgettes [48]. Conventional courgette fruits were also shown to concentrate from 27 [49] to $897 \mathrm{mg} / \mathrm{kg}$ f.w. [50] of nitrates. A smaller range of nitrate content (from 43 [51] to $405 \mathrm{mg} / \mathrm{kg}$ f.w. [52]) was noted in organic vegetable marrow (Cucurbita реро L.) [38]. Studies focused on other crops showed a relation between nitrate concentrations and morphological characteristics of species and cultivars $[38,53]$.

\subsection{Carotenoids Content}

Carotenoids belong to natural plant metabolites with well-documented positive effects on human health. The relationships between carotenoid consumption and protection against the development of several types of cancer, degenerative diseases, sight protection, as well as prevention of many other conditions related to oxidative stress, have been reported [54,55]. Lutein, zeaxanthin and $\beta$-carotene are the main carotenoids found in fruits of Cucurbitaceae family [56,57]. The courgette fruits analyzed within the study contained, on average, $12.31 \pm 0.15 \mu \mathrm{g} / \mathrm{g}$ f.w. of these carotenoids (sum), including 5.02 $\pm 0.09 \mu \mathrm{g} / \mathrm{g}$ f.w. of lutein, $5.08 \pm 0.09 \mu \mathrm{g} / \mathrm{g}$ f.w. of zeaxanthin and $2.21 \pm 0.04 \mu \mathrm{g} / \mathrm{g}$ f.w. $\beta$-carotene. Fruits grown in 2012 were generally richer in lutein and $\beta$-carotene, but contained less zeaxanthin compared to those grown in 2013 (Table 3). In effect, the summary concentration of all the three carotenoids did not differ significantly between years. Moreover, the tested courgette cultivars differed significantly in the concentrations of lutein and $\beta$-carotene in the fruit. Soraya was characterized by the highest content of lutein, while Lajkonik was richest in $\beta$-carotene. The agronomic system did not show any significant, consistent effect on the carotenoid profile of the fruits, but some interactions between the agronomic system and the cultivation year as well as between the agronomic system and the courgette cultivar were observed: (a) compared to the conventional cropping system, organic cultivation resulted in slightly higher lutein concentrations in Lajkonik courgettes, but lower lutein concentrations in Atena courgettes, at the same time, no production system effect was observed in the Soraya courgettes; (b) the described differences in the lutein content between courgettes grown in the two cropping systems were observed only in the 2012 (Atena) and 2013 (Lajkonik) growing seasons (Figure 7). No such interactions were observed in the case of carotenoid (sum) and zeaxanthin content.

The content of carotenoids in the fruits of plants belonging to Cucurbita pepo is known to differ significantly depending on the cultivar [29]. Some other studies on green courgettes reported higher carotenoid content than presented in this study [58]. Carotenoids concentrations found in the studied courgettes were much lower than those reported by other authors for Cucurbita maxima and Cucurbita moschata $[57,59]$. The authors of another available published study pointed that darker green colored summer squash had higher concentrations of carotenoids [60]. The effects of morphological features of different cultivars on the carotenoids profiles were also demonstrated in winter squash fruits [57]. The proportion of $\beta$-carotene to lutein in the present study is in line with the results of other authors [29]. 

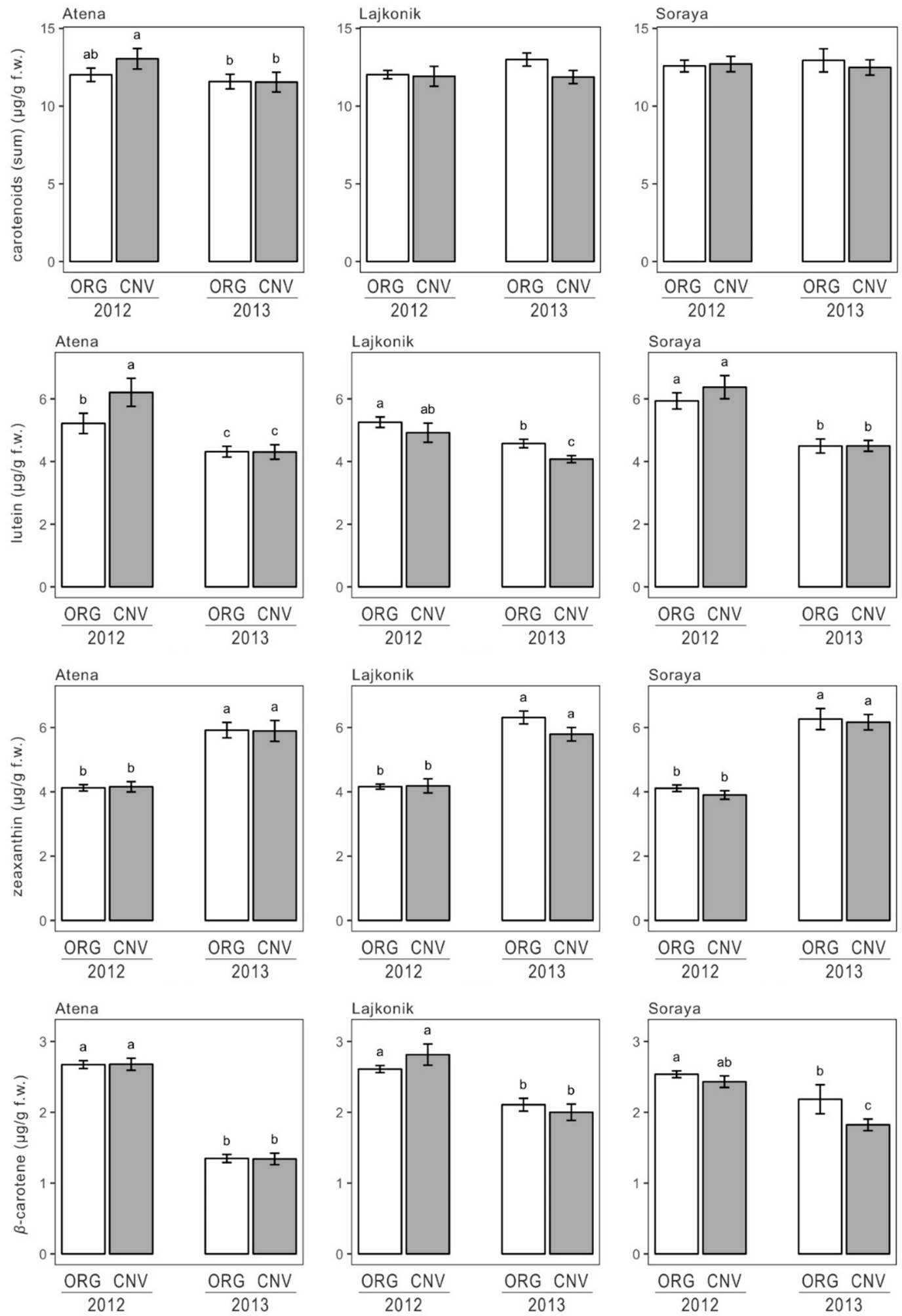

Figure 7. Carotenoids (sum), lutein, zeaxanthin and $\beta$-carotene content in organic (ORG) and conventional (CNV) courgette fruits of Atena, Lajkonik and Soraya cultivars grown in two consecutive years. Data are presented as means with standard errors. Within each cultivar, bars marked with the same letters are not significantly different at the $5 \%$ level of probability.

The available research focused on the impact of agronomic practices on the carotenoids concentrations in squashes is limited. However, one of the studies has shown that the concentrations 
of carotenoids in scallop squash are inversely related to the dose of the nitrogen fertilizer used in the cultivation [21].

\subsection{Chlorophyll Content}

The courgette fruits analyzed within the study contained, on average, $4.58 \pm 0.11 \mathrm{mg} / 100 \mathrm{~g}$ f.w. of chlorophylls (sum), including $2.98 \pm 0.08 \mathrm{mg} / 100 \mathrm{~g}$ f.w. of chlorophyll $a$ and $1.60 \pm 0.04 \mathrm{mg} / 100 \mathrm{~g}$ f.w. of chlorophyll $b$. The chlorophyll concentrations in the fruits differed between years, cultivars and agronomic systems (Table 3). Fruits of the cultivars with green skin (especially Lajkonik) were, on average, richer in chlorophylls than those of the yellow-skin cultivar (Atena), although a significant interaction between the cultivar and the year was observed: while Lajkonik fruits were equally rich in chlorophylls (sum) and chlorophyll $a$ in both years, the content of these compounds in the other two cultivars differed between years-in 2012, Atena was found to be richer in chlorophylls than Soraya, and in 2013 the opposite relation was observed (Figure 8). When comparing the concentrations of chlorophylls in the fruit between years (growing seasons), there were no differences in the case of Lajkonik. Atena contained more chlorophylls in 2012 vs. 2013, while Soraya did in 2013 vs. 2012.
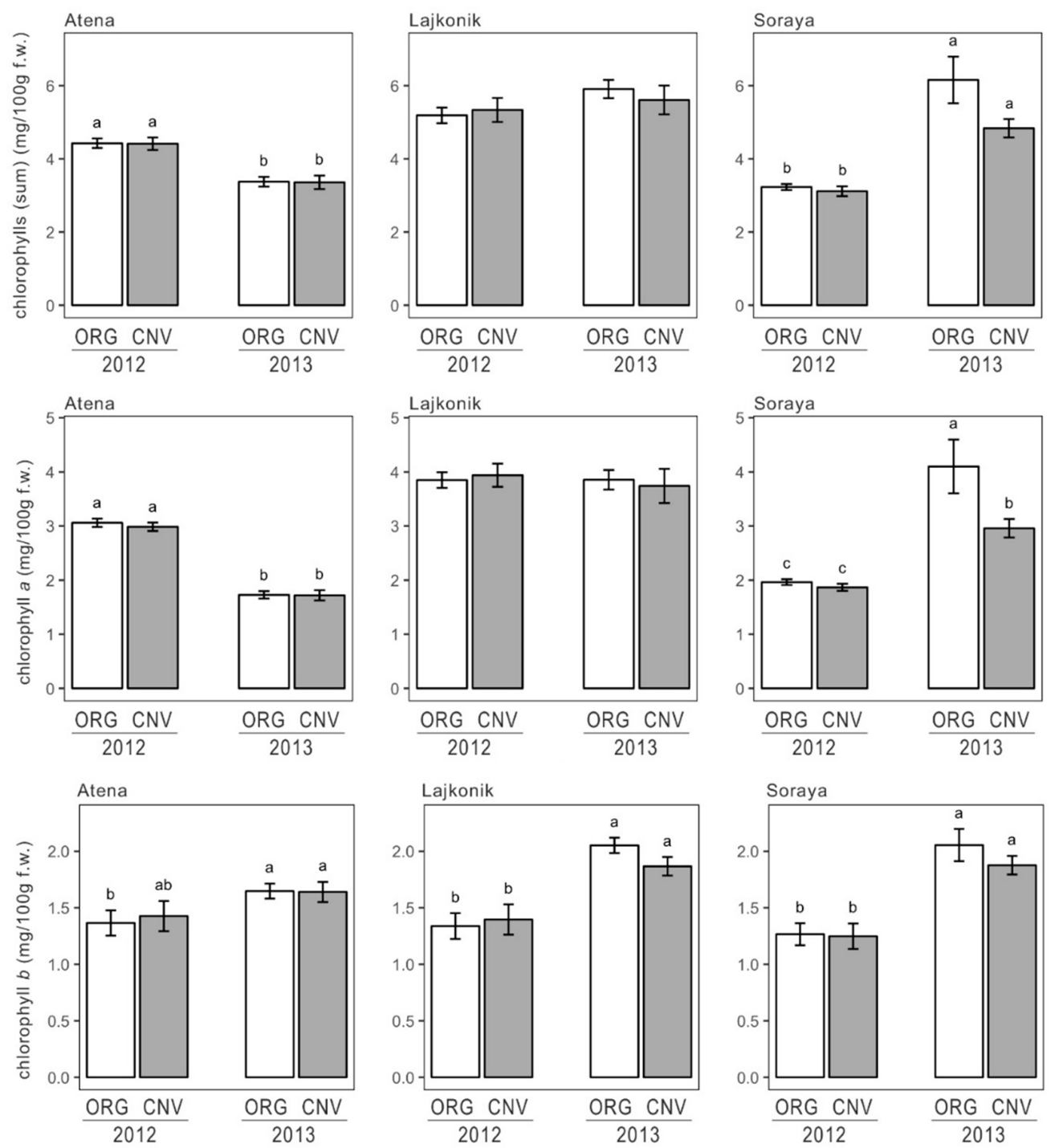

Figure 8. Chlorophylls (sum), chlorophyll $a$ and chlorophyll $b$ content in organic (ORG) and conventional $(\mathrm{CNV})$ courgette fruits of Atena, Lajkonik and Soraya cultivars grown in two consecutive years. Data are presented as means with standard errors. Within each cultivar, bars marked with the same letters are not significantly different at the $5 \%$ level of probability. 
The 3-factor ANOVA detected also a significant agronomic system effect on the concentrations of chlorophylls (sum) and chlorophyll $a$ in the courgette fruits (Table 3), with organically grown fruits being significantly richer in these compounds. However, when analyzing results separately for all cultivars and the two years, this effect was significant only in the case of Soraya cultivar grown in 2013 (Figure 8). Some studies reported higher concentrations of chlorophylls in summer squash fruits grown with organic fertilizer compared to the control treatment [61]. At the same time, higher chlorophyll concentrations were observed in conventional compared to organic courgette leaves [62]. This can be explained by the fact that the chlorophylls contain nitrogen in their structure, and thus easily assimilable, soluble mineral nitrogen in the conventional system can result in enhanced synthesis of chlorophylls $[63,64]$. Chlorophyll, as a bioactive compound found in green vegetables, is the most abundant of all natural pigments, and plays an important role in the biosynthetic processes of chloroplasts in plants [65]. This pigment and its derivatives have been shown to possess strong antioxidant and anti-mutagenic properties, modulate xenobiotics metabolizing enzymes and induce apoptosis of cancer cells. The growing scientific interest in the effectiveness of diets rich in phytochemicals in cancer prevention has increased interest in chlorophyll as a compound with potential preventive effects. Considering the low toxicity of chlorophylls, and their abundance in plant raw materials such as leafy vegetables and courgettes, these substances of natural origin may be ideal candidates in the prevention of diseases caused by oxidative stress, including cancers [65-67].

\section{Conclusions}

Nowadays, farmers are forced to search for strategies to produce crops of a high quality, providing optimal yield as well as minimizing the negative impact of agricultural practices on the environment. Organic agriculture is one of the systems developed to address these principles. Results of this study show that besides the farming system (organic vs. conventional) many factors influence the fruit yield, as well as the chemical composition (carotenoids, chlorophylls, nitrates and nitrites) of the courgette fruits. The growing season, represented by the different weather conditions, appeared to have a predominant effect on the yield as well as the majority of the analyzed compositional parameters of the courgette fruits. The studied cultivars also differed significantly in the concentration of lutein, $\beta$-carotene, and chlorophylls, although some significant interactions between the cultivar and the growing season were observed. On average, organically grown courgettes were characterized by a significantly higher yield, as well as higher dry matter and chlorophyll content, however, this agronomic system's effect was not consistent among all the studied cultivars in the two seasons. This superfluous study suggests that, in the case of courgette, cultivation organic practices have the potential to provide high yields of good-quality fruit, comparable to (or, in the case of some parameters, better than) conventional, resource-intensive horticulture. Considering the limited number of similar research studies on courgettes, the presented results give some first insight into the characteristics of courgette fruits grown in extensive horticultural systems, and could therefore be of interest to growers and consumers. Their importance could be underlined by the fact that organic farming has been a fast-developing sector in agriculture of European countries in recent decades and organic food products, including vegetables, are in high and constantly growing demand. Although the courgette cultivars tested in this study are common on the Polish market, their growing conditions reflect the typical cultivation of courgettes. Thus, the presented results could be an indication for planters from other countries on the expected quality characteristics and yield of courgette fruits. Nevertheless, further studies should be encouraged, with attention paid to other courgette cultivars, and to the interactions between plant genotype, geographical location and agronomic system/practices, to validate the presented conclusions.

Author Contributions: Conceptualization, K.K., R.K., D.Ś.-T. and E.H.; Data curation, K.K., D.Ś.-T., M.B. and E.H.; Formal analysis, K.K., M.B. and E.H.; Funding acquisition, D.Ś.-T.; Investigation, K.K., R.K., D.Ś.-T., A.S., M.B. and E.H.; Methodology, K.K., D.S.-T., A.S., M.B., E.R. and E.H.; Resources, A.S. and E.H.; Software, M.B. and E.H.; Supervision, R.K. and D.Ś.-T.; Visualization, M.B. and E.H.; Writing—original draft, K.K., D.Ś.-T. and 
E.H.; Writing-review \& editing, K.K., R.K., D.Ś.-T., A.S., M.B. and E.H. All authors have read and agreed to the published version of the manuscript.

Funding: This research was funded by the Polish Ministry of Science and Higher Education with funds of the Institute of Human Nutrition Sciences, Warsaw University of Life Sciences (WULS), for scientific research. The publication charges are covered with a grant from the Financial Support System for Scientists and Research Teams in the Warsaw University of Life Sciences (awarded in 2020 to D.S.-T., grant number 504-02-780400-S00123-99).

Conflicts of Interest: The authors declare no conflict of interest. The funders had no role in the design of the study; in the collection, analyses, or interpretation of data; in the writing of the manuscript, or in the decision to publish the results.

\section{References}

1. Martínez-Valdivieso, D.; Gómez, P.; Font, R.; Río-Celestino, M. Del Mineral composition and potential nutritional contribution of 34 genotypes from different summer squash morphotypes. Eur. Food Res. Technol. 2014, 240, 71-81. [CrossRef]

2. Paris, H.S. Germplasm enhancement of Cucurbita pepo (pumpkin, squash, gourd: Cucurbitaceae): Progress and challenges. Euphytica 2016, 208, 415-438. [CrossRef]

3. Eurostat Statistics. Available online: https://ec.europa.eu/eurostat/web/agriculture/data (accessed on 30 August 2020).

4. Korzeniewska, A.; Sobocińska, D.; Romać, M.; Niemirowicz-szczytt, K. Charakterystyka jednopędowych form cukinii (Cucurbita pepo L.). Pol. J. Agron. 2013, 12, 26-31.

5. Lust, T.A.; Paris, H.S. Italian horticultural and culinary records of summer squash (Cucurbita pepo, Cucurbitaceae) and emergence of the zucchini in 19th-century Milan. Ann. Bot. 2016, 118, 53-69. [CrossRef] [PubMed]

6. Salehi, B.; Sharifi-rad, J.; Capanoglu, E.; Adrar, N. Cucurbita Plants: From Farm to Industry. Appl. Sci. 2019, 9, 3387. [CrossRef]

7. Tillman, J.; Nai, A.; Batzer, J.; Gleason, M. Strip-tillage and Row Cover Use in Organically and Conventionally Grown Summer Squash. Iowa State Res. Farm Prog. Rep. 2015, 2187, 7-10.

8. European Parliament; European Council. Regulation (EU) 2018/848 of the European Parliament and of the Council of 30 May 2018 on Organic Production and Labelling of Organic Products and Repealing Council Regulation (EC); No. 834/2007; European Parliament; European Council: Brussels, Belgium, 2018.

9. United Nations. Transforming Our World: The 2030 Agenda for Sustainable Development; United Nations: New York, NY, USA, 2015; Volume 70, p. 1.

10. Barański, M.; Rempelos, L.; Iversen, P.O.; Leifert, C. Effects of organic food consumption on human health; the jury is still out! Food Nutr. Res. 2017, 61,1-5. [CrossRef]

11. Barański, M.; Średnicka-Tober, D.; Volakakis, N.; Seal, C.; Sanderson, R.; Stewart, G.B.; Benbrook, C.; Biavati, B.; Markellou, E.; Giotis, C.; et al. Higher antioxidant and lower cadmium concentrations and lower incidence of pesticide residues in organically grown crops: A systematic literature review and meta-analyses. Br. J. Nutr. 2014, 112, 794-811. [CrossRef]

12. European Food Safety Authority. The 2017 European Union report on pesticide residues in food. EFSA J. 2019, 17, 5743.

13. Carrillo, C.; Wilches-Pérez, D.; Hallmann, E.; Kazimierczak, R.; Rembiałkowska, E. Organic versus conventional beetroot. Bioactive compounds and antioxidant properties. LWT 2019, 116, 108552. [CrossRef]

14. Brandt, K.; Leifert, C.; Sanderson, R.; Seal, C. Agroecosystem management and nutritional quality of plant foods: The case of organic fruits and vegetables. CRC Crit. Rev. Plant Sci. 2011, 30, 177-197. [CrossRef]

15. Curl, C.L.; Fenske, R.A.; Elgethun, K. Organophosphorus pesticide exposure of urban and suburban preschool children with organic and conventional diets. Environ. Health Perspect. 2003, 111, 377-382. [CrossRef] [PubMed]

16. Smith-Spangler, C.; Brandeau, M.L.; Hunter, G.E.; Bavinger, J.C.; Pearson, M.; Eschbach, P.J.; Sundaram, V.; Liu, H.; Schirmer, P.; Stave, C.; et al. Are organic foods safer or healthier than conventional alternatives? A systematic review. Ann. Intern. Med. 2012, 157, 348-366. [CrossRef] [PubMed]

17. Willer, H.; Schlatter, B.; Trávníček, J.; Kemper, L.; Lernoud, J. (Eds.) The World of Organic Agriculture Statistics and Emerging Trends 2020, 21st ed.; Research Institute of Organic Agriculture (FiBL): Frick, Switzerland; IFOAM-Organics International: Bonn, Germany, 2020. 
18. Suvo, T.; Ahamed, M.; Haque, M.; Chakrobarti, M.; Biswas, H. Identification of suitable media based on hydroponic culture for production Zucchini squash. Int. J. Agric. Res. Innov. Technol. 2017, 6, 1-4. [CrossRef]

19. Liopa-Tsakalidi, A.; Barouchas, P.; Salahas, G. Response of Zucchini to the Electrical Conductivity of the Nutrient Solution in Hydroponic Cultivation. Agric. Sci. Procedia 2015, 4, 459-462. [CrossRef]

20. Sałata, A.; Stepaniuk, R. Growth, yield and quality of zucchini "soraya" variety fruits under drip irrigation. Acta Sci. Pol. Hortorum Cultus 2013, 12, 163-172.

21. Balbierz, A.; Kołota, E. The effects of nitrogen fertilization and stage of fruit maturity at harvest on yield and nutritional value of scallop squash. Acta Sci. Pol. Hortorum Cultus 2017, 16, 33-43. [CrossRef]

22. Souza, F.I.D.; Grangeiro, L.C.; Souza, V.F.L.D.; Gonçalvez, F.D.C.; Oliveira, F.H.T.; Jesus, P.M.M.D. Agronomic performance of Italian zucchini as a function of phosphate fertilization. Rev. Bras. Eng. Agric. Ambient. 2018, 22, 206-211. [CrossRef]

23. Polish Norm PN-EN Fruits and Vegetable Juices-Determination of Dry Matter-Gravimetric Method; The Polish Committee for Standarization: Warsaw, Poland, 2001.

24. Polish Norm PN-R-04013:1988 The Estimation of Dry Matter in Fruits and Vegetables; The Polish Committee for Standardization: Warsaw, Poland, 1988; pp. 1-5.

25. Polish Norm PN-EN 12014-Foodstuffs. Determination of Nitrate and/or Nitrite Content. HPLC/IC Method for the Determination of Nitrate Content of Vegetables and Vegetable Products; The Polish Committee for Standarization: Warsaw, Poland, 2001.

26. Hallmann, E.; Kazimierczak, R.; Marszałek, K.; Drela, N.; Kiernozek, E.; Toomik, P.; Matt, D.; Luik, A.; Rembiałkowska, E. The nutritive value of organic and conventional white cabbage (Brassica oleracea L. var. Capitata) and anti-apoptotic activity in gastric adenocarcinoma cells of sauerkraut juice produced therof. $J$. Agric. Food Chem. 2017, 65, 8171-8183. [CrossRef]

27. Średnicka-Tober, D.; Ponder, A.; Hallmann, E.; Głowacka, A.; Rozpara, E. The profile and content of polyphenols and carotenoids in local and commercial sweet cherry fruits (Prunus avium L.) and their antioxidant activity in vitro. Antioxidants 2019, 8, 534. [CrossRef]

28. R Core Team. An Introduction to R.; R Foundation for Statistical Computing: Vienna, Austria, 2019.

29. Martínez-Valdivieso, D.; Gómez, P.; Font, R.; Alonso-Moraga, Á.; Del Río-Celestino, M. Physical and chemical characterization in fruit from 22 summer squash (Cucurbita pepo L.) cultivars. LWT Food Sci. Technol. 2015, 64, 1225-1233. [CrossRef]

30. Harvey, W.J.; Grant, D.G.; Lammerink, J.P. Physical and sensory changes during the development and storage of buttercup squash. N. Z. J. Crop Hortic. Sci. 1997, 25, 341-351. [CrossRef]

31. Murphy, E.F.; Hepler, P.R.; True, R.H. An evalutaion of the sensory qualities of inbred lines of squash (Cucurbita maxima). J. Am. Soc. Hortic. Sci. 1996, 89, 483-490.

32. Pevicharova, G.; Velkov, N. Sensory, chemical and morphological characterization of Cucurbita maxima and Cucurbita moschata genotypes from different geographical origins. Genetika 2017, 49, 193-202. [CrossRef]

33. Conti, S.; Villari, G.; Amico, E.; Caruso, G. Effects of production system and transplanting time on yield, quality and antioxidant content of organic winter squash (Cucurbita moschata Duch.). Sci. Hortic. 2015, 183, 136-143. [CrossRef]

34. Neocleous, D.; Savvas, D. Modelling Ca2+accumulation in soilless zucchini crops: Physiological and agronomical responses. Agric. Water Manag. 2018, 203, 197-206. [CrossRef]

35. Zhou, Y.; He, W.Z.; Zheng, W.L.; Tan, Q.L.; Xie, Z.Z.; Zheng, C.S.; Hu, C.X. Fruit sugar and organic acid were significantly related to fruit Mg of six citrus cultivars. Food Chem. 2018, 259, 278-285. [CrossRef]

36. Barker, A.V.; Stratton, M.L. Nutrient Density of Fruit Crops as a Function of Soil Fertility, 1st ed.; Srivastava, A.K., Hu, C., Eds.; Elsevier: Amsterdam, The Netherlands, 2020; ISBN 9780128187326.

37. Kołota, E.; Balbierz, A. Effects of nitrogen fertilization on the mineral status of plants and the chemical composition of scallop squash fruits. J. Elem. 2017, 22, 1255-1267.

38. Colla, G.; Kim, H.J.; Kyriacou, M.C.; Rouphael, Y. Nitrate in fruits and vegetables. Sci. Hortic. 2018, 237, 221-238. [CrossRef]

39. Maggio, A.; De Pascale, S.; Paradiso, R.; Barbieri, G. Quality and nutritional value of vegetables from organic and conventional farming. Sci. Hortic. 2013, 164, 532-539. [CrossRef]

40. McKnight, G.M.; Duncan, C.W.; Leifert, C.; Golden, M.H. Dietary nitrate in man: Friend or foe? Br. J. Nutr. 1999, 81, 349-358. [CrossRef] [PubMed] 
41. Machha, A.; Schechter, A.N. Inorganic nitrate: A major player in the cardiovascular health benefits of vegetables? Nutr. Rev. 2012, 70, 367-372. [CrossRef] [PubMed]

42. Lundberg, J.O.; Weitzberg, E.; Gladwin, M.T. The nitrate-nitrite-nitric oxide pathway in physiology and therapeutics. Nat. Rev. Drug Discov. 2008, 7, 156-167. [CrossRef] [PubMed]

43. Herencia, J.F.; García-Galavís, P.A.; Dorado, J.A.R.; Maqueda, C. Comparison of nutritional quality of the crops grown in an organic and conventional fertilized soil. Sci. Hortic. 2011, 129, 882-888. [CrossRef]

44. Danilcenko, $\mathrm{H}$. The research on biochemical composition, culinary values and usability for processing of pumpkin family vegetables. Rocz. Akad. Rol. Pozn. Ogrod. 2000, 31, 245-252.

45. Kołota, E.; Balbierz, A. Yield potential and fruit quality of scallop squash (Cucurbita pepo L. var. patissonina Greb. f. radiata Nois.) cultivars grown for processing. Acta Agrobot. 2015, 68, 261-266. [CrossRef]

46. Montemurro, F.; Fiore, A.; Campanelli, G.; Tittarelli, F.; Ledda, L.; Canali, S. Organic fertilization, green manure, and vetch mulch to improve organic zucchini yield and quality. HortScience 2013, 48, 1027-1033. [CrossRef]

47. Rouphael, Y.; Colla, G.; Battistelli, A.; Moscatello, S.; Proietti, S.; Rea, E. Yield, water requirement, nutrient uptake and fruit quality of zucchini squash grown in soil and closed soilless culture. J. Hortic. Sci. Biotechnol. 2004, 79, 423-430. [CrossRef]

48. Kołota, E.; Adamczewska-Sowińska, K. Application of synthetic mulches and flat covers with perforated foil and agrotextile in zucchini. Acta Sci. Pol. Hortorum Cultus 2011, 10, 179-189.

49. Yordanov, N.D.; Novakova, E.; Lubenova, S. Consecutive estimation of nitrate and nitrite ions in vegetables and fruits by electron paramagnetic resonance spectrometry. Anal. Chim. Acta 2001, 437, 131-138. [CrossRef]

50. Tomme, E.H.; van Devijvere, S.; Vinkx, C.; Huybrechts, I.; Goeyens, L.; van Oyen, H. Average daily nitrate and nitrite intake in the Belgian population older than 15 years. Food Addit. Contam. Part A Chem. Anal. Control. Expo. Risk Assess 2011, 28, 1193-1204. [CrossRef] [PubMed]

51. Gonzalez, M.C.M.; Martinez-Tome, M.J.; Isasa, M.E.T. Nitrate and nitrite content in organically cultivated vegetables. Food Addit. Contam. 2010, 3, 19-29. [CrossRef] [PubMed]

52. Herencia, J.F.; Ruiz-Porras, J.C.; Melero Garcia-Galvais, P.A.; Morillo, E.C. Comparison between organic and mineral fertilization for soil fertility levels, crop macronutrient concentrations, and yield. Agron. J. 2007, 99, 4. [CrossRef]

53. Burns, I.G.; Zhang, K.; Turner, M.K.; Mecham, M.; Al-Redhiman, K.; Lynn, J.; Bradley, M.R.; Hand, P.D.P. Screening genotypesand environment effects on nitrate accumulation in 24 species of young lettuce. J. Sci. Food Agric. 2011, 91, 553-562. [CrossRef]

54. Cicero, A.F.G.; Colletti, A. Effects of Carotenoids on Health: Are All the Same? Results from Clinical Trials. Curr. Pharm. Des. 2017, 23, 1-6. [CrossRef]

55. Zaccari, F.; Galietta, G. a-carotene and b-carotene content in raw and cooked pulp of three mature stage winter squash "type butter-nut". Foods 2015, 4, 477-486. [CrossRef]

56. Martínez-Valdivieso, D.; Font, R.; Blanco-Díaz, M.T.; Moreno-Rojas, J.M.; Gómez, P.; Alonso-Moraga, Á.; Del Río-Celestino, M. Application of near-infrared reflectance spectroscopy for predicting carotenoid content in summer squash fruit. Comput. Electron. Agric. 2014, 108, 71-79. [CrossRef]

57. Bonina-Noseworthy, J.; Loy, J.B.; Curran-Celentano, J.; Sideman, R.; Kopsell, D.A. Carotenoid concentration and composition in winter squash: Variability associated with different cultigens, harvest maturities, and storage times. HortScience 2016, 51, 472-480. [CrossRef]

58. Eissa, H.A.; Bareh, G.F.; Ibrahim, A.A.; Moawad, R.K.; Ali, H.S. The effect of different drying methods on the nutrients and non-nutrients composition of zucchini (green squash) rings. J. Appl. Sci. Res. 2013, 9, 5380-5389.

59. Armesto, J.; Rocchetti, G.; Senizza, B.; Pateiro, M.; Barba, F.J.; Domínguez, R.; Lucini, L.; Lorenzo, J.M. Nutritional characterization of Butternut squash (Cucurbita moschata D.): Effect of variety (Ariel vs. Pluto) and farming type (conventional vs. organic). Food Res. Int. 2020, 132, 109052. [CrossRef]

60. Del Río-Celestino, M.; Gómez, P.; Villatoro-Pulido, M.; Moya, M.; Domínguez-Pérez, I.; Martínez-Valdivieso, D.; Font, R.; Muñoz Serrano, A.; Alonso-Moraga, A. Quantification of carotenoids in zucchini (Cucurbita pepo L. subsp. pepo) cultivars cultivated in Almeria by liquid chromatography. Acta Hortic. 2012, 939, 183-187. [CrossRef]

61. Sarhan, T.Z.; Mohammed, G.H.; Teli, J.A. Effect of Bio and Organic Fertilizers on Growth, Yield and Fruit Quality of Summer Squash. Sarhad J. Agric. 2011, 27, 378-380. 
62. Palmer, M.W.; Cooper, J.; Tétard-Jones, C.; Średnicka-Tober, D.; Barański, M.; Eyre, M.; Shotton, P.N.; Volakakis, N.; Cakmak, I.; Ozturk, L.; et al. The influence of organic and conventional fertilisation and crop protection practices, preceding crop, harvest year and weather conditions on yield and quality of potato (Solanum tuberosum) in a long-term management trial. Eur. J. Agron. 2013, 49, 83-92. [CrossRef]

63. Song, H.; Li, Y.; Xu, X.; Zhang, J.; Zheng, S.; Hou, L.; Xing, G.; Li, M. Analysis of genes related to chlorophyll metabolism under elevated $\mathrm{CO}_{2}$ in cucumber (Cucumis sativus L.). Sci. Hortic. 2020, 261, 108988. [CrossRef]

64. Pokluda, R.; Shehata, S.M.; Kopta, T. Vegetative, Chemical Status and Productivity of Zucchini Squash (Cucurbita pepo L.) Plants in Responses to Foliar Application of Pentakeep and Strigolactones Under NPK Rates. Gesunde Pflanz. 2018, 70, 21-29. [CrossRef]

65. Ferruzzi, M.G.; Blakeslee, J. Digestion, absorption, and cancer preventative activity of dietary chlorophyll derivatives. Nutr. Res. 2007, 27, 1-12. [CrossRef]

66. Mishra, V.K.; Bacheti, R.K.; Husen, A. Medicinal uses of chlorophyll: A critical overview. Chlorophyll Struct. Prod. Med. Uses 2011, 177-196.

67. Chu, M.; Li, H.; Wu, Q.; Wo, F.; Shi, D. Pluronic-encapsulated natural chlorophyll nanocomposites for in vivo cancer imaging and photothermal/photodynamic therapies. Biomaterials 2014, 35, 8357-8373. [CrossRef]

(C) 2020 by the authors. Licensee MDPI, Basel, Switzerland. This article is an open access article distributed under the terms and conditions of the Creative Commons Attribution (CC BY) license (http://creativecommons.org/licenses/by/4.0/). 